\title{
Student's Readiness Level towards Implementation of paper 3 Subject History
}

Siti Aishah Suhaimi', Mohd Mahzan Awang², Anuar Ahmad ${ }^{3}$

${ }^{1}$ Faculty of Education, The National University of Malaysia

2 Faculty of Education, The National University of Malaysia

${ }^{3}$ Faculty of Education, The National University of Malaysia

${ }^{1}$ ct_shah56@yahoo.com, 2mahzan@ukm.edu.com, ${ }^{3}$ anuarahmadukm@gmail.com

\begin{tabular}{ccc}
\hline Received & Accepted & Published \\
$10 / 04 / 2017$ & $19 / 06 / 2017$ & $31 / 07 / 2017$ \\
\hline & DOI \\
& $10.26523 /$ yupa.v1i2.57 \\
\hline
\end{tabular}

Abstract This study focuses on the student towards paper implementation 3 subject of history. This study use where survey research design as many as 50 from respondent 4 in School orchid, Cheras, chosen by gregarious sample and use instrument in obtaining quantitative data. This research using Social learning theory Albert Bandura, theory of constructivism and also Bloom's Taxonomy model. Data analyzed by using Excel Microsoft software 2010 (Statistic pack) 2.0 (SPSS). Finding of correlation analysis show there is a significant relationship between student attitude approach with students' knowledge towards paper of 3 history subject $(r,=.846=, n=50$, $p<.0 .5)$. Therefore, the paper 3 subject of history is seen as platform that is able to increase the understanding and performance of students in the general history often associated with subjects that are boring and hard to get better performance by students in examinations due to lack of interest, learning techniques are obsolete and inadequate learning.

Keywords: readiness level student, implementation of paper 3 subject of history

\begin{abstract}
Abstrak Penelitian ini berfokus pada siswa terhadap implementasi kertas 3 subjek sejarah. Penelitian ini merupakan penelitian survey terhadap 50 responden dari kelas 4 di Sekolah Orchid, Cheras menggunakan sampel berkelompok dan instrumen guna memperoleh data kuantitatif. Penelitian ini menggunakan teori belajar sosial Albert Bandura, teori konstruktivisme dan juga model Taksonomi Bloom. Data dianalisis dengan menggunakan perangkat lunak Microsoft Excel 2010 (Paket Statistik) 2.0 (SPSS). Temuan analisis korelasi menunjukkan adanya hubungan yang signifikan antara pendekatan sikap siswa dengan pengetahuan siswa terhadap kertas 3 subjek sejarah ( $r,=, 846=, n=50, p<.0 .5)$. Oleh karena itu, makalah 3 mata pelajaran sejarah dipandang sebagai platform yang mampu meningkatkan pemahaman dan kinerja siswa dalam sejarah umum yang sering dikaitkan dengan mata pelajaran yang membosankan dan sulit mendapatkan kinerja yang lebih baik oleh siswa dalam ujian karena kurangnya minat, teknik pembelajaran sudah usang dan pembelajarannya tidak memadai..
\end{abstract}

Kata Kunci: level kesiapan siswa, implementasi paper 3, mata pelajaran sejarah 


\section{INTRODUCTION}

Ministry of Education makes the subject of history as a compulsory subject in 2013 at SPM seen very significant in the current context. Further, make it a core subject for primary schools starting in 2014. This is in line with the transformation of the national education system, namely KSSR changes to KBSR starting in 2011. This in turn will elevate the position of this subject in the eyes of the public. Supported by Shakila Yacob (2010) see the steps require the subject's history aim to standardize historical knowledge in Malaysia, show interest and historical knowledge relevant in every Malaysian life aspect and strengthen Malaysian history legacy which reflects parallel social diversity with 1 Malaysian struggle.

The new format Subject History Paper 1249/3 implemented from 2013. The objective of the Paper 3/1249 history is to provide opportunities for students to answer questions, prevent students from getting marks empty, student can pluck again sentence from textbook and scholarly books about question asked to get score and question enacted based upon fom textbook 4 and from 5. At the same time, teachers can guide students to identify the title of the theme than likely be out of the question that is just a title that can only be developed contents can be asked in the paper 1249/3. Teachers can also help students to choose reading materials that are suitable include textbooks or other academic materials. In addition, the history of paper 3 is weighted $20 \%$ and the time allocated to candidates answered three hours.

According to Modise Mosothwane (1995), the education history of the particular curriculum when it was found that existing curriculum does not meet the goals and needs of a country to cope with the changes that occur in the present and future. Curriculum changes made with the hope of enhancing the quality and efficiency of education. Based on the above statement, it can be concluded that national policy makers are very sensitive to the importance of this subject as a vision of the future in the process of building the unity of the nation and the country. Policies require secondary school students learn history is national education Philosophy to the needs (FPK) looking for the development of physical, emotional, spiritual and intellectual students simultaneously and integrated. Prior to this Historical subject are treated as second class and subjects associated with the students of Arts (Abdul Ghani 2008).

School Inspector's report finds that the subject of history is less interested by the students because it considers the subject very boring and too difficult to understand. The students' quality statement report published by the Malaysian Examinations Board (LPM) in SPM between 2008 and 2009 summarizes the weaknesses in responding to historical questions because of the weakness of students in the mastery of facts and concepts of understanding, content processing and short answers with simple content as well as less skilled discuss and think (Bahari Md Shah, 2011). The statement was supported by Abdul Razak and Abdullah (2000) on 240 students in the Petaling Jaya and Kuala Selangor districts that the students 
regarded the History subject as an ineffective subject. This response is associated with History subjects that do not provide job security and have no commercial value (Sivachanlingam et al., 2008).

\section{METHOD}

In an effort to achieve objective of the study, survey design used in this study is survey research. Survey research used to explain certain phenomenon with generalizes way survey results to population (Chua 2006). The survey method can also collect information from each individual by using the same question (Jackson 2006). The sample was a Form 4 student at Orkid Desa, Cheras, Kuala Lumpur.

The number of samples will be taken according to Krejcie, RV and Morgan D.W schedule. Aimed at obtaining high and accurate data reliability. Based on population size of 60 students, for this study researchers took 50 respondents. Validity and reliability are an important feature of a measuring instrument (Salkind 2006). The concept of reliability is different from legality. The reliability of the research instrument was tested in order to ensure the validity and stability of the measuring instrument before the actual assessment was carried out (Yahya 2006). While validity is the truth of the measuring instrument used (Gravetter \& Forzana 2009) and is closely related to the question of whether the instrument provides the information required by the researcher (Beins 2004). In this study, the researcher uses the method of consistency in alpha cronbach to make assumptions that each item in the questionnaire is used as an equivalent test

The questionnaire in this study was provided by the researcher himself. There are four divisions: Part A: Background, Part B: Student exposure level on paper 3 historical subjects, Part C: Student attitude level with paper 3 historical subjects and Part D: Student knowledge level on paper question 3 historical subjects. For each stimulus or question item is in Likert scale.

Table 1. Likert Scale

\begin{tabular}{ccccc}
\hline $\mathbf{1}$ & $\mathbf{2}$ & $\mathbf{3}$ & $\mathbf{4}$ & $\mathbf{5}$ \\
\hline Not at all & rarely & $\begin{array}{c}\text { Frequent } \\
\text { medium }\end{array}$ & frequrent & Very often \\
\hline
\end{tabular}

\begin{tabular}{ccccc}
\hline $\mathbf{1}$ & $\mathbf{2}$ & $\mathbf{3}$ & $\mathbf{4}$ & $\mathbf{5}$ \\
\hline Strongly disagree & Do not agree & Disagree & Agree & Very agree \\
\hline
\end{tabular}




\section{RESULT AND DISCUSSION}

Table 2. Gender

\begin{tabular}{ccc}
\hline Gender & Frequency & Percent \% \\
\hline Male & 23 & 46 \\
Female & 27 & 54 \\
Total & $\mathbf{5 0}$ & $\mathbf{1 0 0}$ \\
\hline
\end{tabular}

Based on Table 2 shows the results of the study found that the majority of respondents by gender shows are women is 27 (54\%) and male students compared to 23 (46\%) students.

\section{Analysis of the level of preparedness of students Mean score on the implementation of the paper 3 subjects History}

Table 3. Distribution of Mean level of exposure of students to the paper 3 Subjects History

\begin{tabular}{|c|c|c|c|c|}
\hline No & $\begin{array}{c}\text { Item Level } 3 \text { disclosures Students Against Paper } \\
\text { Subjects History }\end{array}$ & Mean & $\begin{array}{l}\text { Standard } \\
\text { Deviation }\end{array}$ & Interpreting \\
\hline 1. & $\begin{array}{l}\text { I gained exposure by teachers on techniques of } \\
\text { answering the question paper } 3 \text { subjects history. }\end{array}$ & 2.52 & .762 & Average \\
\hline 2. & $\begin{array}{l}\text { I gained exposure on paper } 3 \text { through training } \\
\text { conducted by the teacher. }\end{array}$ & 2.92 & .488 & Average \\
\hline 3. & $\begin{array}{l}\text { I gained exposure on paper } 3 \text { history by following the } \\
\text { additional classes }\end{array}$ & 2.26 & .443 & Low \\
\hline 4. & $\begin{array}{l}\text { I secured exposure paper } 3 \text { through reading } \\
\text { materials. }\end{array}$ & 3.08 & .601 & Average \\
\hline 5. & $\begin{array}{l}\text { I secured exposure paper } 3 \text { through discussions with } \\
\text { a friend. }\end{array}$ & 2.76 & .847 & Average \\
\hline 6. & $\begin{array}{l}\text { I secured exposure paper } 3 \text { through workshops in } \\
\text { historical subjects run by the school. }\end{array}$ & 3.26 & .847 & Average \\
\hline 7. & $\begin{array}{l}\text { I gained exposure on paper } 3 \text { through the activities } \\
\text { performed by the teacher. }\end{array}$ & 3.52 & .664 & Average \\
\hline 8. & $\begin{array}{l}\text { I obtain exposure on paper } 3 \text { through question and } \\
\text { answer done by teacher }\end{array}$ & 3.44 & .675 & Average \\
\hline & Total & 2.97 & & Average \\
\hline
\end{tabular}

Analysis of the findings in respect of the level of exposure of students to the history of paper 3 subjects showed an average level with mean score is 2.97. Thus, to improve the orientation of learning towards performance goals and a willingness to learn by (Hassan Haris 1993) argued about the importance of understanding the concept before the thought process of history, but the same response was also noted by (Mohamad Johdi Salleh, 2004) and (Abdul Razak Ahmad, 1999). Among the way students approach the subjects of history must start from the concept of evaluating the reasons, the chronology of events and make the interpretation by providing examples that came with your existing knowledge and experience of students. 
In addition, to improve the exposure of students to the paper 3 subjects are history by Snowomen et al (2011) noted that effective communication between the partners in the group plays a big role in increasing the motivation to achieve success. Also, it can promote the use of collaborative approaches (technology, communication and team skills) between teachers and students as well as sharing knowledge with colleagues where a collaborative approach could help them learn more effectively (Sumarlin \& Eka Murdani, 2015).

Table 4. Distribution of the mean level of the attitude of students with paper 3 Subjects History

\begin{tabular}{|c|c|c|c|c|}
\hline No & $\begin{array}{c}\text { Item Level attitude of students with Question } \\
\text { paper } 3 \text { Subjects History }\end{array}$ & Mean & $\begin{array}{l}\text { Standard } \\
\text { Deviation }\end{array}$ & Interpreting \\
\hline 1. & $\begin{array}{l}\text { I give full concentration during history teacher lesson } \\
\text { in class. }\end{array}$ & 2.98 & .685 & Average \\
\hline 2. & I revise paper of 3 history subject in free time. & 2.66 & .717 & Average \\
\hline$S$ & $\begin{array}{l}\text { I make } 3 \text { paper training subjects history though not } \\
\text { asked by the teacher. }\end{array}$ & 2.34 & .593 & Average \\
\hline 4. & $\begin{array}{l}\text { I make a note and short note when revise paper of } 3 \\
\text { histories subject. }\end{array}$ & 2.32 & .683 & Low \\
\hline 5. & I ask questions to the teacher in the classroom. & 2.56 & .705 & Average \\
\hline 6. & $\begin{array}{l}\text { I complete all assignments instructed by teachers by } \\
\text { referring information given. }\end{array}$ & 2.84 & .650 & Average \\
\hline 7. & $\begin{array}{l}\text { I asked the teacher to choose suitable reading } \\
\text { material including textbook / other academic } \\
\text { material. }\end{array}$ & 2.98 & .589 & Average \\
\hline 8. & Promote the learning of history I think. & 2.92 & .752 & Average \\
\hline 9. & $\begin{array}{l}\text { I interact and discuss with friend to understand } \\
\text { question papers of } 3 \text { history subject. }\end{array}$ & 2.86 & .756 & Average \\
\hline 10. & $\begin{array}{l}\text { I convey information, relevant facts history thinking } \\
\text { concept clearly with friend. }\end{array}$ & 2.58 & .642 & Average \\
\hline & Total & 2.70 & & Average \\
\hline
\end{tabular}

Analysis found that the level of students' attitudes Paper 3 subjects with a history of moderate average mean score is 2.70. Supported in the study of Abdul Razak et. al, (2009) which states that most students have the impression that the subject of history is a boring subject and lead to less attention and fewer students are motivated to learn history (Azwani bin Ismail et. al).

Thus, interest in the subject of history is difficult nurtured and reinforced by a lackluster student achievement in the subjects of history reinforces the stigma that the subject of history is a subject that is difficult and complicates the students to get a score in the exam. The inventory should include information on student, content or topics that will be discussed, teaching materials and so on. Preparation of teaching has three key components, namely component preparation, presentation and closing (Mok, SS, 2002). Completion, students should be motivated to improve the training of paper 3 subjects' history, ask questions in class, interact 
and discuss with partners to understand the history of paper 3 subjects, constantly making notes and short notes and so on.

Table 5. Distribution of Students in Knowledge Mean Subjects History

\begin{tabular}{llcc}
\hline No & Knowledge & Mean & Interpreting \\
\hline 1. & Understanding & 2.55 & Average \\
2. & Application & 2.48 & Average \\
3. & Analysing & 2.34 & Average \\
4. & Evaluation & 2.56 & Average \\
5. & Generate Idea & 2.62 & Average \\
6. & Value & 2.56 & Average \\
\hline
\end{tabular}

Table 6. Distribution of Min Level Knowledge Students in Paper 3 Subjects History

\begin{tabular}{|c|c|c|c|c|}
\hline No & $\begin{array}{l}\text { Item Level Knowledge Students in Paper } 3 \text { Subjects } \\
\text { History }\end{array}$ & Mean & $\begin{array}{l}\text { Standard } \\
\text { Deviation }\end{array}$ & Interpreting \\
\hline \multicolumn{5}{|c|}{ Understanding } \\
\hline 1. & I understand the historical facts rationally. & 2.74 & .664 & Average \\
\hline 2. & $\begin{array}{l}\text { I can describe the characteristics and development } \\
\text { factor in something happening. }\end{array}$ & 2.24 & .771 & Low \\
\hline 3. & I can associate information with an event. & 2.96 & .638 & Average \\
\hline 4. & I can identify a true story or fiction & 2.50 & .863 & Average \\
\hline & $\begin{array}{l}\text { I understand historical importance as a knowledge } \\
\text { discipline in life. }\end{array}$ & 2.34 & .688 & Average \\
\hline \multicolumn{5}{|c|}{ Application } \\
\hline 6. & I can apply history resources in exams. & 2.34 & .848 & Average \\
\hline 7. & $\begin{array}{l}\text { I use knowledge and information (concepts, theories, } \\
\text { principles) was then applied in new situations. }\end{array}$ & 2.26 & .751 & Low \\
\hline 8. & $\begin{array}{l}\text { I can apply the importance of history as a discipline in } \\
\text { life }\end{array}$ & 2.56 & .787 & Average \\
\hline 9. & I can apply the historical facts rationally. & 2.56 & .705 & Average \\
\hline & $\begin{array}{l}\text { I use the knowledge (empathy) then is applied in } \\
\text { myself }\end{array}$ & 2.70 & .763 & Average \\
\hline \multicolumn{5}{|c|}{ Analysing } \\
\hline 11. & I distinguish past history and now. & 2.66 & .823 & Average \\
\hline 12. & $\begin{array}{l}\text { I analyze and make an inference behind incident which } \\
\text { occurred. }\end{array}$ & 2.58 & .731 & Average \\
\hline & I can distinguish the concept of cause and effect & 2.32 & .683 & Low \\
\hline 14. & I can explain to a friend the facts and opinions. & 2.22 & .790 & Low \\
\hline $\begin{array}{l}15 . \\
\text { Eval }\end{array}$ & $\begin{array}{l}\text { I can analyse facts of history rationally. } \\
\text { luation }\end{array}$ & 1.94 & .620 & Low \\
\hline 16. & I can evaluate concept and consequences. & 2.56 & .787 & Average \\
\hline 17. & I can able to assess the past and now & 1.92 & .601 & Low \\
\hline 18. & I can evaluate facts of history rationally. & 2.98 & .515 & Average \\
\hline 19. & I can argue with friends about historical facts. & 2.42 & .810 & Average \\
\hline 20. & $\begin{array}{l}\text { I can assess reasons the occurrence of a historical } \\
\text { event. }\end{array}$ & 2.96 & .807 & Average \\
\hline \multicolumn{5}{|c|}{ Generate Idea } \\
\hline 21. & $\begin{array}{l}\text { Teacher always draw conclusion from history } \\
\text { resources. }\end{array}$ & 2.68 & .768 & Average \\
\hline 22. & I can explain and arrange chronology of certain & 2.40 & .728 & Average \\
\hline
\end{tabular}


incident.

23. I explaining way or steps until sparked a historical 2.66 event.

24. I can combine information from various sources.

2.78

.745

Average

25. I can justify the first source and a second source.

2.60

.648

Average

\section{Value}

26. I can say value of certain historical event.

2.44

.756

Average

27. I can make consideration of certain incident with regard various cons aspect and pros.

28. I can evaluate historical importance as a life

2.44

.687

Average

.733 Average

knowledge discipline.

29. By understanding the value of an event I can learn

.627

Average

from historical experience.

30. By making the assessment of an event I can improve thinking ability and maturity.

Total

2.44

.907

Average

2.36

.598

Average

2.51

Average

Table 5 shows the distribution of the overall value Mean Level of Knowledge in the question paper 3 subjects history at a moderate level average mean score is 2.51.Among the items to understand, apply, analyze, evaluate, generate ideas and values of each distribution that is mean $2: 55,2: 48,2: 34,2: 56,2.62$ and 2.56 .

Analysis found that the level of students' knowledge of the history of paper 3 subjects at a moderate level average mean score is high level 2.51. KBAT happen if a person acquires new information and store the information and then make contact with the previous information with the aim of obtaining the solution in each complex problems (Tran Vui 2006) quoted from the study (Bakry et.al 2013). In addition, students will be increased knowledge and interest to explore particularly involving subject's increasingly impressive history. Therefore, teachers need to be smart in doing various activities to foster learning styles for thinking towards higher.

\section{Analysis of the Relationship Between the attitudes of students with the knowledge of students on the paper 3 Subjects History}

The analysis found that there is a significant correlation between the approaches of the correlation value attitudes in the classroom with the students' knowledge of the history of paper 3 subjects. This shows the Pearson coefficient, $r$, is .846, a significant correlation $(p<.05)$ that describe in table 7 below 
Table 7. Relationship between students' attitudes toward students with knowledge papers 3 Subject History

\begin{tabular}{|ll|r|r|}
\hline & & Attitude & Knowledge \\
\hline \multirow{4}{*}{ Attitude } & Pearson Correlation & 1 & $.846^{* *}$ \\
& Sig. (2-tailed) & & .000 \\
& $\mathrm{~N}$ & 50 & 50 \\
& Pearson Correlation & $.846^{* *}$ & 1 \\
Knowledge & Sig. (2-tailed) & .000 & \\
& $\mathrm{~N}$ & 50 & 50 \\
& & & \\
\hline
\end{tabular}

Accordingly, the implementation of the 3 subjects in the history of the paper should be accompanied by an involvement by the two parties, namely the teachers and students, as teachers will affect the students' attitudes and knowledge. Disclosure of paper 3 subjects of history should be a major agenda in our education system so that teachers and students know the importance and usefulness of this HOTS approach to understanding and achievement. Courses on HOTS should be intensified to increase knowledge of teachers thereby can implement it as a platform in the success KBAT during the process of teaching and learning in the classroom. Not only the importance, but also the rules, teaching styles and features as well as matters related to HOTS also need to be enlightened in order that teachers can generally KBAT effectively.

A study conducted by Khairi (2000) Critical Thinking in Teaching History Perspective Form Four students in Teluk Intan, aims to look at the perspective of four students on teaching critical thinking skills from the point of view of history teachers. This research aims at showing the extent of the history teacher teaching critical thinking skills that emphasize aspects of Bloom's Taxonomy. The study also looked at the methods and means used by teachers of history and forms of questioning which is emphasized by a history teacher. Therefore, this clearly shows that the component has been around and thinking skills depend on the interpretation of teachers and how teachers can plan and carry out HOTS in class. While Rosli (1998) who studied the effects of teaching critical thinking on Student Achievement in History Form Two, also discussed that teachers play a role in the teaching of critical thinking skills and how the students and student achievement on teaching thinking skills can enhance the comprehension and achievement students.

There are several types of teaching aids that can be used in the process of learning. Among pictorial and graphic materials such as photographs, charts, posters, postcards and globes, through visual aids such as transparencies, slides and film strips, radio and headset such 
as tape recordings and audio-visual equipment such as a television and film. In addition, the source materials as historical artifacts, historical documents and archaeological remains are also suitable for use during lessons.

\section{CONCLUSION}

HOTS or higher-order thinking skills that are applicable in the paper 3 with history is a step that is so beneficial to be implemented to bring reforms in the education system in our country as well as improve and become an important approach in improving students' academic performance. With that, the paper 3 subjects of history is seen as a platform that is able to increase the understanding and performance of students in the history of the public is often associated with subjects that are boring and hard to get better performance by students in examinations due to lack of interest, learning techniques are outdated and lack of learning.

\section{REFERENCES}

Ariegusrini B. Agus \& Mohamad Johdi Bin Salleh.2009.Kreativiti pengajaran dan pembelajaran Sejarah. Dlm. Abdul Razaq \&Isjoni.Transformasi pengajaran dan pembelajaran Sejarah (hlm. 183 - 96). Penerbitan bersama: Fakulti Pendidikan, Universiti Kebangsaan Malaysia, Bangi; dan, FKIP, Universitas Riau, Pekan Baru.

Aini Mahabbati.2012. Analisa teori belajar sosial bandura mengenai gangguan perilakau agresif pada anak.Jurnal Pendidikan Khusus.2:1-12.

Bakri, Md Nor Bakar dan Firdaus .2013. Kemahiran Berfikir Aras Tinggi Di Kalangan Guru Matematik Sekolah Menengah Pertama Di Kota Makassar.International Seminar On Quality And Affordable Education.

Creswell, J.W. 2008. Educational Research: Planning, Conducting and Evaluating Quantitative and Qualitative Research. USA: Pearson.

Caroline@Lorena David dan Abdul Said Ambotang .2014. Profesionalisme Guru Novis Dalam Pengurusan Pengetahuan, Kesediaan Mengajar Dan Kemahiran Berfikir Aras Tinggi (KBAT) Terhadap Pelaksanaan Pengajaran Di Sekolah. Seminar Kebangsaan Integriti Keluarga.

Department of Education and Training.2005.Recognition of pior learning (skill recognition):An assessment resource for vet practitioners.

Endacott, J.2010.Reconsidering baffective engagement in historical empathy.Theory and Research in Social Education, 38(1), 6-49.

Holt, K. 2011. Digital Approaches to Teaching World History. The Middle Ground Journal, 1(2), 1-12.

Hergenhahn, B.R., Olson, Matthew H. 1997. An Introduction to Theories of Learning,3 ${ }^{\text {rd }}$ edition. New Jersey: Prentice-Hall International

Jinggan, A. A. 2015.Pengajaran Terhadap Percapaian Akademik Dalam Mata Pelajaran Sejarah. Kukikulum \& Pengajaran Asia Pasifik, Fakulti Pendidikan Universiti Kebangsaan Malaysia. 
Kamarul Azmi Jasmi, Ab. Halim Tamuri, Mohd Faeez Ilias dan Mohd Izhan Mohd Hamzah. 2011. Amalan Penggunaan Bahan Bantu Mengajar dalam Kalangan Guru Cemerlang Pendidikan Islam Sekolah Menengah Di Malaysia.Journal of Islamic and Arabic Education. 3(1): 59-74.

Lee Bih N.ICT dan Pengajaran dan Pembelajaran Sejarah Di Sekolah. Seminar Pendidikan Sejarah dan Geografi. Universiti Malaysia Sabah pada 29-30 Ogos 2013.

Nur Syazwani binti Abdul Talib, Mohd Mahzan B. Awang, Abdul Razaq B. Ahmad, 2015. Penggunaan Kepelbagaian Sumber Dalam Pendidikan Sejarah Dan Hubungannya Dengan Minat Belajar Sejarah. Seminar Penyelidikan Kebangsaan, Fakulti Pengurusan Ekonomi Universiti Pendidikan Sultan Idris pada 9 May.

Norakma Mohd Daud, Abdul Razak, Noria Munirah Yakub.2015.Pembelajaran berteraskan kemahiran berfikir aras tinggi (KBAT) di dalam pengajaran dan pembelajaran mata pelajaran sejarah. Proceedings: 7th International Seminar on Regional Education, hlm.5-7.

Mahanom Mohamad. 1998. Analisis Kemahiran Pemikiran Sejarah dalam Bahan Kurikulum Peringkat Menengah Rendah. Tesis Sarjana, Universiti Kebangsaan Malaysia.

Pushpalatha A/P Sivamugam.2006.Kemahiran Berfikir Aras Tinggi dalam Sukatan Pelajaran Sejarah Tingkatan Empat: Satu Kajian Kes. Fakulti Sains Kognitif dan Pembangunan Manusia Universiti Pendidikan Sulatan Idris.

Pn.Tong Shu Lan.2013.Gabungan pendekatan konstruktivisme dan Behaviorlisme bagi meningkatkan prestasi mata pelajaran sejarah tingkatan tiga. Seminar Pendidikan Sejarah dan Geografi. 29 - 30 Ogos.

Rosniza Aznie C.Rose.2010.Peningkatan pendidikan menjejaskan fertiliti penduduk tempatan: Konfirmasi dari pembangunan Besut Baru Terengganu. Malaysian Journal of Society and Space. 6(2): 51-62.

Sharifah Nor, P. \& Kamarul Azman, A.S. 2011. Tahap kesediaan penggunaan ICT dalam pengajaran dan kesannya terhadap hasil kerja dan tingkah laku murid prasekolah. Jurnal Pendidikan Malaysia, 36(1): 25-34.

Sharifah Nor Puteh, Rohaty Mohd. Majzub \& Zahirah Mohd.Yusof. 2010 . Peranan guru dan penggunaan ICT dalam pengajaran dan pembelajaran kepelbagaian pelajar. Dalam Pendidikan untuk Kepelbagaian Pelajar, Rohaty Majzub, Kamisah Osman, Sharifah Nor Puteh. (pnyt.) Fakulti Pendidikan, UKM.

Subadrah Nair.2005.Penggunaan model konstruktivisme lima fasa needham dalam pembelajaran sejarah.Jurnal Pendidik dan Pendidikan. 20:21-41.

Wilbinah Bahoi.2013.Kaedah soalan sejarah kertas 3 SPM pentaksiran 2013 proses pengajaran dan pembelajaran mata pelajaran sejarah: Meningkatkan semangat patriotism murid.Seminar Pendidikam Sejarah dan Geografi. 29-30. Ogos. 